\title{
Malignant Pancreatic Neoplasm
}

National Cancer Institute

\section{Source}

National Cancer Institute. Malignant Pancreatic Neoplasm. NCI Thesaurus. Code C9005.

A primary or metastatic malignant tumor involving the pancreas. Representative examples include carcinoma and lymphoma. -- 2003 